\title{
SPTBN2 Gene
}

National Cancer Institute

\section{Source}

National Cancer Institute. SPTBN2 Gene. NCI Thesaurus. Code C106018.

This gene plays a role in actin filament function. 